\title{
Theories and Contemporary Development of Organizational Perspectives in Social Sciences. The development of organizational theory and the emergence of challenges to the traditional rational approaches to understand the organization. Part 2
}

\author{
Medani P. Bhandari ${ }^{1}$, \\ ${ }^{1}$ Akamai University, \\ Hilo, Hawaii, USA
}

\begin{abstract}
This paper is purely theoretical in which I have illustrated the contributions of the founding theorist of Western sociology, by focusing on how they addressed (or didn't address) organizations. Then, I have discussed (in brief) the development of organizational theory and how organizational theorists are responding to the emergence of challenges to the traditional rational approaches to understanding organizations. These analyses are situated on the historical contexts include major contributions of each theorist. This research is solely based on the secondary information. Paper contents four Sections: first the work of the three founding theorists of Western Sociology, Karl Marx; Émile Durkheim and Max Weber, secondly, I have exemplified the development of organizational theory and the emergence of challenges to the traditional rational approaches to understand the organization; where $I$ have analyzed the work of Classical theorists- Max Weber, Henri Fayol, Frederick Taylor, Luther Halsey Gulick, Herbert A. Simon, Berton H. Kaplan, modern theorist- Michel Foucault, Jurgen Habermas, Jacques Derrida, Jurgen Habermas etc. Third Section covers the contemporary theories and perspectives. In this section I have exemplified how Philip Selznick, Peter Blau, James David Thompson and Charles Perrow incorporated the Weber notion of bureaucracy followed by DiMaggio, Paul, J. and Walter W. Powell etc. and in forth section, covers the feminist approach in theory building with focus of organizational analysis (with the focus of Arlene Daniels, Dorothy Smith, Marjorie DeVault, Gisela Bock and Susan James, Martha Calas, Linda Smircich etc. work). This paper has detailed footnotes quoted from the original sources and contents useful reference of the sociological theory and practices for concerned social scientist to build their knowledge base and research direction.
\end{abstract}

ASEJ - Scientific Journal of Bielsko-Biala School of Finance and Law

Volume 24, No 1 (2020), 6 pages

DOI: $10.5604 / 01.3001 .0014 .1343$

Received: 06 April 2020; Accepted: 10 April 2020
Index Terms - International Organizations, International Relation, Organizational Sociology, Organizational Theory, Classical Sociology, Contemporary Theories,

\section{INTRODUCTION}

Organizational theory has a long history associated with major fields of social sciences such as sociology, economics, political science, public administration, anthropology and social psychology. Organizational study covers multiple viewpoints, methods and levels of analysis. It ranges from micro level individual behavior of organizations to macro level organizations, where one can analyze a variety of organizational settings and their behavior; such as why they are founded, how they developed, in what structures they build and what are their functions. It also covers which strategy they use to function, and what procedure they apply to sustain the organization. Further organizational study covers the broader ground of their productivity (knowledge, power, wealth and services), and studies their products on the basis of their respective niches. Several scholars (classical Weber, Foyal, Taylor to contemporary Scott, Smircich etc.) have examined organizational forms at formal and informal levels. The unit of analysis of organization varies from micro, macro and meso level according to the organizations size and their connections.

There are several paradigms to examine organizations such as in terms of power dynamism, culture, networks (within organizations and with individuals) or population or ecological

Regular research paper: Published 30 April 2020

Corresponding author's e-mail: medani.bhandari@gmail.com

Copyright $(\mathbb{C} 2018$ This is an open access article distributed under the Creative Commons Attribution CC-BY-NC 4.0 License. 
perspectives with the application of both qualitative and quantitative methods. Organizational theory also examines the bureaucratic order within the organization and evaluates how individuals interact in or with organizations and maintain their role to administrate the organization. It also analyses the control mechanism, its model (particularly bureaucratic), and explains how such modality works in terms of product and production delivery to the society. Therefore, organizational study is multidimensional and can be examined in various perspectives. Many scholars have been working in this field. Most important are the founders of Sociology such as Karl Marx, Ferdinand Tönnies, Émile Durkheim, Ludwig Gumplovicz, Vilfredo Pareto, and Max Weber and Talcott Parsons and many others have discussed formal and informal forms of social organizations (Ritzer 2000). Among the classical sociologists especially, Max Weber (1864-1920) introduced the concept of bureaucracy and Karl Marx (1818-1883) and Emile Durkheim (1858-1917) developed the concept of division of labor as a founding concept of the formal basis for organizational sociology. Organizational sociology is rooted through the sociological canon but not limited to it. Organizational sociology is also highly influenced by public administration and business management studies, political science and psychology. In another words organizational analysis very complex and is not limited to sociological epistemology only.

\section{Classical theorists}

Significant authors of three major classical epistemologies in organizational theory building include:

Max Weber and his concept of rational bureaucracy (ideal, rational form of organization, organizational structure based on rationalization of collective activities, based on formal rules and regulations, impersonal relationships and employment based entirely on technical competence);

Henri Fayol (French industrialist and general administration theorist who was contemporary to Weber), who developed five basic grounds for organization management i.e. planning, organizing, commanding, coordinating and controlling. He further developed fourteen principles of administrative management of organizations i.e. division of labor, authority and disciple, unity of command and direction, subordination of individual interests to the general interests, remuneration and centralization, scalar chain, order, equity stability of tenure of personnel, initiative and sprit de corps;

Frederick Taylor, another important organizational theorist, developed the scientific management theory of organizations. Taylor described four major principles: 1) scientific job analysis (observation, data gathering, and careful measurement determine "the one best way" to perform each job); 2) selection of personnel (scientifically select and then train, teach, and develop workers); 3) management cooperation (managers should cooperate with workers to ensure that all work is done in accordance with the principles of the science that developed the plan), and 4) functional supervising (managers assume planning, organizing, and decision-making activities, and workers perform jobs) (Scott 2003, Fincham and Rhodes
1999).

In addition to these major classical organization theorists; Luther Halsey Gulick (1892-1992) was another who followed the Fayol theoretical path and developed new organizational management theory. Gulick proposed planning, organizing, staffing, directing, coordinating, controlling and budgeting as key principles for good organization management. Another most influential organizational theorist was Herbert A. Simon (1916-2001), who extensively contributed to large areas of social sciences and technological fields (cognitive psychology, computer science, public administration, economics, management, philosophy of science and sociology). He was critical of Fayol and Taylor's organizational theory (Scott 2003). He examined organizational behavior in rational ground, as proposed by Max Weber, and added work on how rationality fits management of the organization. Simon analyzed organization in six major categories, i.e. objectively, subjectively, consciously, deliberately and organizationally rational. Simon presented a series of five contradictions in organizational behavior, nicely summarized by Brown (2004) i.e. 'the prime importance of the scientific paradigm, which is crucial to the legitimacy of his proposition; the view of administrative science from the logical positivist position; the positing of an objective world for the organization; the inclusion of psychology, allowing room for speculation about the decision maker in terms of "motivation" rather than "drive"; and the provision of "space" for the complexity of subjective intent and voluntarism'. Simon's book Administrative Behavior was published in 1947. According to him the aim of the book was to show how organizations can be understood in terms of their decision processes (Simon, 76). Simon treats decision-making as the heart of administrative behavior. He states that administration must be based on the logic and psychology of human choice, i.e. economic theory and psychology (Bakka and Fivesdal, 1986, p. 168). Simon provides the practical ground to explain his organizational theory.

Like Simon, Berton H. Kaplan (1968) deals with bureaucracy in the context of social dynamism and social development. Kaplan proposes six alternatives: (1) that the organization is theoretically oriented; (2) that the organization is designed to provide latent structures to meet the changing contingencies of the development process; (3) that the organization is client centered and is consequently designed to work with the entire social system(s); (4) that the organization is designed to perform a socialization or esocialization function; (5) that social development organizations are ideally committed to a norm emphasizing experimental design as the primary consideration in program design; (6) and that the organization for social development is constrained by the limited alternatives for change available at any given time" (Kaplan 1968, p. 471).

Kaplan's list does not reject the seven parameters of good bureaucracy of Weber but provides the refined way to see the system in the changing social situation. He provides an alternative definition on the basis of current demand of organization which focuses on the problem solving and program design approaches. The author states that "a 
development bureaucracy is assumed to involve the following elements: (1) the management of change, that is, the direction of efforts to alter the basic pattern(s) of a way of life; (2) the design of structures to plan change, that is, the specification of workable criteria of organizational structure to effect and direct a change process; and (3) the focus on the goal of altering the whole "way of life" or parts of it, so as to increase the adaptive capacities of individuals and groups" (Kaplan 1968 p. 472). The basis of problems in organizations, Kaplan (1968) points out, are to be found in the basic values and structural features of development bureaucracies, the range of structures, transactions between bureaucracy and environment, and the input-output system (page 472). He suggests that the bureaucracy model needs to consider the changing sociological phenomena. His notion is practical and insists organizational sociologists should reexamine the organizational status with consideration of the socio-political and economic demands of the time.

However, all the classical theorists have been heavily criticized by the contemporary organizational theorists particularly since the late 1950s. As Argyris (1957) objects, classical organizational theorists did not consider the workers perspectives. He states that workers have minimal control over their working lives. Likewise, Graeme Salaman states that "a genuine sociology of organizations is not assisted by the efforts of some organization analysts to develop hypotheses about organizations in general, lumping together such diverse examples as voluntary organizations, charities and political organizations ... It also obstructs the analysis of those structural elements which are dramatically revealed in employing organizations, but not necessarily in all forms of organization" (Salaman 1979: 33, as cited by Thompson and McHugh 2002: 6). Zey-Ferrell (1981) has summarized the major criticisms of organizational theories mostly with reference to the comparative structural and structural contingency approaches.

To address the criticisms of organizational theories, various systems perspectives have been developed particularly from the late 1950s. These system perspectives examine organization in terms of rational (embedded through the work of classical organizational theorists, Taylor, Fayol, Weber and Simon and March and others), natural (including conflict approach, functionalist analysis of organization Durkheim, Malinowski, Radcliffe-Brown, Parson) Barnard's cooperative system, Selznick, Perrow, and Mayer: institutional approach, Mayo: Hawthorne effect, and open system (based on social movements: Bertalanffy, Boulding: Systems Simon and March 1958 etc.) (c.f. Scott 2003). According to Kuhn (1983) all three - the natural, rational, and open systems perspectives - are functional and they do not need to be verified. All three have importance and co-exist and have different methodologies. Each of them has different value and each is based on different rhetoric. Kuhn's summary captures the notion of system perspectives, because they are interlinked one way or another. Similar notions can be found in the works of Granovetter (1985), Weick (1976), Buckley (1967) and Pondy and Mitroff (1979) as well as Guillen (1994), Pfeffer (1982), Burrell and Morgan (1979) and Beniger (1986) who analyze organizational theory with the combined perspectives.

Furthermore, based on Weber bureaucratic principles, sociologists view organizations as social systems, organizations as negotiated orders, organizations as structures of power and domination, organizations as symbolic constructions, organizations as social practices, as well as power structures and power struggles, the nature of social practices, and ideology and culture. In other words most of the social sciences epistemologies have been applied to study organizations with different grounds, economic (Williamson 1975: transaction cost approach), market and labor (Pfeffer and Cohen 1984, and Uzzi 1993), ecology (Carroll 1984, Hannan and Freeman 1977), environment (Tushman and Anderson 1986), organization as networks (Fligstein 1985, Davis and Stout. 1992, Chandler 1962, Uzzi 1996, Powell 1990), and so on.

In terms of organization theories, there are wide rages of applications such as contingency theory (Lawrence \& Lorsch 1967, Galbraith 1974, Ness and Brechin 1988), cultural theory (Louis 1985, Weick 1985), critical and conflict theory (Marxist) theory (Burawoy 1979) and by the feminist organizational sociologists. Likewise, institutional theory (Meyer and Rowan 1977, Zucker 1983, Selznick 1984 and DiMaggio and Powell 1983), management theory (Hackman 1975, 1995, Kerr 1975), Network Theory (Granovetter 1973, Powell 1990), organizational learning (March and Olsen 1975, Baum and Jintendra 1994, Cohen and Levinthal 1990) and population ecology theory (Astley1985, Carrol and Hannan 1989) have been applied to conduct organizational analysis.

The application of postmodern approaches in organizational study is a recent phenomenon. Most importantly from the 1990s the application of Foucault's perspectives to study of organization is growing. Feminist organizational sociologists such as Joanna Brewis, Marta B. Calás; Linda Smircich are extensively utilizing this approach (see the final section of this essay). Other theoretical approaches most commonly in practice in organizational analysis are resource dependency theory (Salancik 1978, Pfeffer 1982, 1992) sense making (Weick 1976), work and technology (Perrow 1983, Ness and Brechin 1988) and socialization theory (Maanen 1977, Maanen and Barley 1984, and Maanen and Schein 1979). In addition to above mentioned theories in organization there is also radical theory which is very likely to change critical and conflict theory (Mansfield and Warner 1975, Clegg and Dunkerley 1980). Perrow's complex organization and Goffman's Asylum are also considered as radically viewed theories (as noted by Bradley and Wilkie 1980). These lists of works give a general scenario of how multidisciplinary organization theories are changing and how broadly this subfield of sociology is growing. Each of the above-mentioned paradigms have their own paths and methods, though mainstream organizational sociology is mostly woven in and around Weber's theory of bureaucracy and is confined in his bureaucratic iron cage.

Most of the authors have highlighted that the effectiveness of the systems perspective is achieved through an emphasis of setting specific goals, prescribing the behavioral expectations of organizational participants through formalization of rules and roles, and monitoring conformance to these expectations. 
These concepts originated with Weber, Taylor, and Simon. The concept of management control came from Frederick Taylor, who explored the notion of scientific management. New models are emerging. A critical attribute model, a cause and effect model and strategy models are still in use but the networking model is the emerging and logical rational perspective; for which logic was based on the natural, open perspective; most recently, a new logic environment-oriented, network system. New technologies, particularly computer-generated models, are providing new paths of analysis of social organizations.

In the following paragraphs I will note how Philip Selznick, Peter Blau, James David Thompson and Charles Perrow incorporated the Weber notion of bureaucracy followed by DiMaggio, Paul, J. and Walter W. Powell. In the final section of this writing I will note the feminist contribution in organizational theory building.

Philip Selznick follows Weber's principles of bureaucracy. He states that from the last decade of the 19th century, Max Weber's notion of bureaucracy has a strong influence in the academic field particularly in Europe and from second decade of 20th century in United States academia (Philip Selznick 1943). In addition to appreciation of Weber works Selznick has provided a different frame of organization as structure. Philip Selznick (1943) proves his four hypotheses i.e. "every organization creates an informal structure, in every organization, the goals of the organization are modified (abandoned, deflected, or elaborated) by processes within it and the process of modification is effected through the informal structure (Selznick 1943 p. 47). The actual procedures of every organization tend to be molded by action toward those goals which provide operationally relevant solutions for the daily problems of the organization as such (page 49)". He examines the research work conducted by Barnard (1940) and Roethlisberger and Dickson (1941) and shows that even smaller organizations have structures and framework for their operation. The beauty of Selznick's article is that he thinks that it is necessary to investigate iron cage of organizational structure for achievement of group goals which creates the paradox to which we have referred (Selznick 1943 p. 48). I see the certain type of boundary Selznick is advocating for the successful organization. In this context Max Weber's metaphor can have an optimistic connotation, because Selznick is illustrating. Weber's notion of bureaucracy to provide empirical evidence for his thesis.

Selznick (1943) examines bureaucracy in the organization from the sociological point of view. He distinguishes the large organization, small organization, formal organization, informal organization; he states that each type of organization has a certain type of structure guided by the nature of the organization. Selznick examines bureaucratization as a process and identifies the criteria i.e. co-operative effort, delegation of functions and action through agents, bifurcation of interest, control mechanism, internal and external relevancy etc. He identifies the problems in such processes but also offers recommendations. Selznick gives importance to hierarchy and power dynamics, abstractions and organizational patterns. His notion of knowledge production follows the same path.
Selznick (1948) provides links to organizational theory i.e. organization as an action system, formal system, concrete organization as economy in an adaptive structure, as cooperative system and as organism. He explains how organizations can be analyzed from the structural and functional points of view. For the formal organizations, the "maintenance of the system" he proposes the following points to consider.

In my opinion these are still applicable, namely (1) The security of the organization as a whole in relation to social forces in its environment; (2) The stability of the lines of authority and communication; (3) The stability of informal relations within the organization; (4) The continuity of policy and of the sources of its determination; (5) A homogeneity of outlook with respect to the meaning and role of the organization (Selznick 1948 pp. 29-32). He proposes selective process principles "Our frame of reference is to select out those needs which cannot be fulfilled within approved avenues of expression and thus must have recourse to such adaptive mechanisms as ideology and to the manipulation of formal processes and structures in terms of informal goals" (Selznick 1948 p. 32). This account actually provides the linkages of organizational theory to the political structure of the society where power dynamics act to maintain the socio-political system. Selznick, Blau, Thompson, Perrow, DiMaggio and Powell also developed their organizational theory from Weber's iron cage paradigm.

Peter Blau (1918-2002) is considered as one of the founders of organizational sociology with Coleman, Gouldner, Lipset, and Selznick (W. Richard Scott and Craig Calhoun's memory note). Blau's major works include 'The Dynamics of Bureaucracy (1955), A Formal Theory of Differentiation in Organizations (1970), The Organization of Academic Work (1973), Parameters of Social Structure (1974), Inequality and Heterogeneity: A Primitive Theory of Social Structure (1977) Structural Contexts of Opportunities (1994) and A Circuitous Path to Macro-structural Theory (1995) solely and many books and journal articles with several other authors. As Scott notes, Blau focused on behavior within white-collar, administrative systems rather than blue-collar settings. As one of the victim of Second World War, Blau captured the notion of changing world, focused upon the system of interrelated elements that characterize the organization as a whole (Blau 1965 p. 325). "The focus.....is the system of interrelated elements that characterize the organization as a whole not its parts" (Blau 1965 p. 326). As did Selznick, Kaplan, Simon and other organizational theorists, Blau also refined Weber's theory of bureaucracy (Argyris 1972).

Through his book 'Exchange and Power in Social Life (1964)' he explained Merton's concept of middle-range theory, and by microeconomic analysis and utility theory, Blau offered a micro-sociology of strategic interaction that anticipated and influenced the later rise of rational choice theory (Coleman, 1990; Cook, 1990 as noted by W. Richard Scott and Craig Calhoun's memory notes). Blau examined organization in a holistic approach. He proposed that organization needs to be examined with close perspectives. He states that differentiation 
makes organization more complex, and complexity generates problems in communication and coordination. In a critique Argyris (1972) states Blau lacks providing concrete definition, and also questions the decentralization concept developed by Blau. However, in organizational theory development, Blau applied a macro-sociological theory of social structure, stratification and a theory of social exchange which laid new ground to analyze formal organizations. A similar notion was applied by James Thompson to identify the distinctive properties of organization.

James David Thompson (1920-1973) examines the new ground of organizations with environmental perspectives. He focuses on uncertainty in the organization because of changing technology and external environment and these changes affect the transactions within the organization, therefore there is uncertainty in the organization. Charles Perrow's works match with Thompson's thesis that technology is a significant external factor for organizational change.

Charles Perrow is one of the leading scholars of organizational sociology, his major works are 'The Radical Attack on Business (1972), Organizational Analysis: A Sociological View (1970), Complex Organizations: A Critical Essay (1972; 3rd ed., 1986), Normal Accidents: Living with High Risk Technologies (1984; revised, 1999), The AIDS Disaster: The Failure of Organizations in New York and the Nation (1990) with Mauro Guillen, Organizing America: Wealth, Power, and the Origins of American Capitalism (2002) and many journal articles. Perrow considers technology as the defining factor of organization. It can be an independent variable and arrangements to get things done can be dependent variables, so organizations should be studied as 'whole' (as Blau and Thompson proposed), rather than by dealing with specific processes or subsections; technology is a better basis for comparing organizations than the several schemes that now exist (Perrow 1967, page 194-95, as cited by Argyris 1972, page 35). Thompson was uncertain about the implication of technology in defining characteristics of the organization; however, Perrow clearly asserts that technology is the major factor for analyzing organizational performance.

DiMaggio and Powell (1983) began their visit into Weberian bureaucracy with the citation to Weber "it is primarily the capitalist market economy which demands that the official business of administration be discharged precisely, unambiguously, continuously, and with as much speed as possible. Normally, the very large, modern capitalist enterprises are themselves unequalled models of strict bureaucratic organization" (Weber 1968:974 as cited by DiMaggio and Powell 1983). Weber reveals the competitive marketplace as the most important force encouraging bureaucratization, arguing that market pressures toward efficiency required the institution of bureaucratic structure because (Weber argued) this is the most precise and efficient administrative form. DiMaggio and Powell argue that the mode of organization has been changed since Weber developed his theory of bureaucracy. They revisit the iron cage in the sense of multiple situations. They argue that "Organizational structure, which used to arise from the rules of efficiency in the marketplace, now arise from the institutional constraints imposed by the state and the professions. The efforts to achieve rationality with uncertainty and constraint lead to homogeneity of structure (institutional isomorphism)". They use the term isomorphism (a mathematical term meaning "constraining process that forces one unit in a population to resemble other units that face the same set of environmental conditions") and divide isomorphism in two categories, competitive and institutional.

Further they examine isomorphism as coercive isomorphism, mimetic processes, normative pressures categories where coercive refers to the pressures from other organizations, government or other agencies; mimetic processes refer to the uncertainty which leads organization to imitate what other organizations are doing: this can be diffused through shifting employees from one organization to another; normative pressure comes from the professionals. They cite Alchian (1950) whose statement clarifies what actually is the mimetic process" "while there certainly are those who consciously innovate, there are those who, in their imperfect attempts to imitate others, unconsciously innovate by unwittingly acquiring some unexpected or unsought unique attributes which under the prevailing circumstances prove partly responsible for the success. Others, in turn, will attempt to copy the uniqueness, and the innovation-imitation process continues" (as cited by DiMaggio and Powell 1983 p. 151). To clarify these processes, they state that "Each of the institutional isomorphic processes can be expected to proceed in the absence of evidence that it increases internal organizational efficiency. To the extent that organizational effectiveness is enhanced, the reason is often that organizations are rewarded for their similarity to other organizations in their fields. This similarity can make it easier for organizations to transact with other organizations, to attract career minded staff, to be acknowledged as legitimate and reputable, and to fit into administrative categories that define eligibility for public and private grants and contracts" (DiMaggio and Powell 1983 p.154).

\section{CONCLUSION}

This explanation provides a new way to evaluate the bureaucracy and presents different perspectives. It is a valid proposition that every organization has its own strength and approaches and also problems and ways to minimize them. However, the changing process mentioned by DiMaggio and Powell is not clear in the sense that they do not explain how this process occurs. In terms of application in my research context DiMaggio and Powell's (1983) findings are worthwhile to consider.

\section{ACKNOWLEDGEMENT}

I acknowledge the input of Mrs. Prajita Bhandari, for creating a peaceful environment to complete this paper and insightful comments and language editing. I would also like to thank to Prameya, Kelsey, Manaslu, Abhimanyu for their insightful comments. I would also thank to Neena (our granddaughter 
who brought the joy in the family so, I was able to concentrate on my job). Especial thanks go to Professors Steven R. Brechin, Peter Ibarra, Marjory for their mentorship to me, without their efforts I would not be able to stand as social theorist. I would also like to thank to the Editor in Chief Prof. Jacek Piotr Binda and Associate Editor Aleksander Sapiński for their encouragements to complete this very theoretical paper. I would also like to thank to the reviewer panel for their input and comments.

\section{REFERENCES:}

Argyris, C. (1957, Personality and organization: The conflict between system and the individual, Harper.

Bradley, David A. and Roy Wilkie (1980), Radical Organization Theory - A Critical Comment, The British Journal of Sociology, Vol. 31, No. 4-574-579.

DiMaggio, P. (2001), Making sense of the contemporary firm and prefiguring its future. In DiMaggio, P. (Ed.), The Twenty-First-Century Firm: Changing Economic Organization in International Perspective. Princeton: Princeton University Press.

DiMaggio, P. (1988), "Interest and agency in institutional theory", in Zucker, L.G. (Eds), Institutional Patterns and Organizations, Ballinger, Cambridge, MA.

DiMaggio, Paul, J. and Walter W. Powell (1983), "The iron cage revisited: Institutional isomorphism and collective rationality in organizational fields," American Sociological Review 48: 147-160.

DiMaggio, P. \& Powell, W. W. (1983), The iron cage revisited: Institutional isomorphism and collective rationality in organizational fields. American Sociological Review, 48:147-160.

Fincham R and Rhodes, P (1999), 'Principles of Organizational Behaviour', Oxford University Press.

Granovetter, M. (1995), Getting a Job: A Study of Contacts and Careers, Chicago, University of Chicago Press.

Granovetter, M. (1985), "Economic Action and Social Structure: the Problem of embeddedness" American Journal of Sociology, 91: 481-510.

Kaplan, Berton H. (1968), Notes on a Non-Weberian Model of Bureaucracy: The Case of Development Bureaucracy, Administrative Science Quarterly, Vol. 13, No. 3, Special Issue on Organizations and Social Development 471-483.

Kuhn, Thomas (1983b), "Rationality and Theory Choice”, Journal of

Mansfield, Pugh, D.S., R., and M. Warner (1975), Research in Organizational Behavior: A British Survey (London: Heinemann Educational Books, 1975).

Pfeffer, J. and G. Salancik (1978), The External Control of Organizations, Harper \& Row.

Ritzer George (2000), Classical Sociological Theory, 3rd edition. New York: McGraw-Hill

Ritzer George (2000), Modern Sociological Theory, McGraw-Hill Humanities/Social Sciences/Languages, 5th edition

Ritzer George (2000), The McDonaldization Thesis: Extensions and Explorations, London: SAGE

Salaman, Graeme and Kenneth Thompson (1980 eds.), Control and Ideology in Organizations Milton Keynes: The Open University Press.

Salaman, Graeme (1979), Organizations, resistance and control, Longman.

Scott, W. R. (2003), Organizations: Rational, Natural \& Open Systems (5th Edition).

Selznick, P. (1984), "Guiding Principles and Interpretation: A Summary" in. TVA and the Grass Roots. Berkeley, UC Berkeley Press: 249-266.
Selznick, Philip (1948), Foundations of the Theory of Organization, American Sociological Review, Vol. 13, No. 1. 25-35

Selznick, Philip (1943), An Approach to a Theory of Bureaucracy, American Sociological Review, Vol. 8, No. 1. 47-54.

Simon, Herbert A. (1976), Administrative Behavior. A Study of DecisionMaking Processes in Administrative Organization, Third Edition, The Free Press, Collier Macmillan Publishers, London, UK, 1976. 